\title{
Influence of Sodium Oxide on Brightness Coefficient of Portland Cement Clinker
}

\author{
D. Mishin ${ }^{(\bowtie)}$ and S. Kovalyov \\ Department of Technology of Cement and Composite Materials, \\ Chemical Technology Institute, Belgorod State Technological University \\ named after V.G. Shukhov, Belgorod, Russia \\ mishinda.xtsm@yandex.ru
}

\begin{abstract}
The paper is devoted to the possibility of adjusting the reflection factor of portland cement clinker. For this purpose, $\mathrm{Na}_{2} \mathrm{CO}_{3}$ is introduced into the slurry of CJSC Belgorod Cement Plant. The influence of $\mathrm{Na}_{2} \mathrm{O}$ on brightness coefficient of the crushed clinker is established at a burning temperature of $1250-1300{ }^{\circ} \mathrm{C}$. With the increase of $\mathrm{Na}_{2} \mathrm{O}$ concentration up to $1-2 \%$ the brightness coefficient is reduced and the increase of $\mathrm{Na}_{2} \mathrm{O}$ in the range of $3.5-7 \%$ leads to sharp increase of the reflection factor and $\mathrm{CaO}_{\text {free }}$ content.
\end{abstract}

Keywords: Sodium oxide $\cdot$ Brightness coefficient $\cdot$ White cement $\cdot$

Free calcium oxide

\section{Introduction}

Modern rotary furnaces of cement industry are characterized by accumulation and circulation of alkali salts in the furnace system (Luginina 2002). As a result, the $\mathrm{R}_{2} \mathrm{O}$ content of furnace charge may reach $3.5 \%$ before the sintering zone, and in some plants this value may even reach $10 \%$. The formation of calcium aluminate ferrite is not observed in furnace charges of alumina industry characterized by high $\mathrm{Na}_{2} \mathrm{O}$ content due to the formation of aluminates and sodium ferrites (Lisiyenko 2004). Hence, as may be expected, the accumulation and circulation of alkali salts will lead to the situation that occurs in furnaces of alumina industry.

Raw mixes from analytical reagents used to obtain $\mathrm{C}_{4} \mathrm{AF}$ are characterized by the formation of sodium compounds instead of calcium compounds (Kovalyov 2015). It will allow obtaining a clinker of lighter shade.

Thus, the purpose of this study is to determine the possibility of adjusting the brightness coefficient of portland cement by introducing sodium oxide into the raw mix.

\section{Methods and Approaches}

The dried slurry of CJSC Belgorod Cement Plant with the following modular characteristics: $\mathrm{KH}=0.91 ; \mathrm{n}=2.23 ; \mathrm{p}=1.29$ was used as a raw mix (Table 1 ). 
Table 1. Chemical composition of slurry of CJSC Belgorod Cement Plant, \%

\begin{tabular}{l|l|l|l|l|l|l|l|l|l}
\hline Losses on ignition & $\mathrm{SiO}_{2}$ & $\mathrm{Al}_{2} \mathrm{O}_{3}$ & $\mathrm{Fe}_{2} \mathrm{O}_{3}$ & $\mathrm{CaO}$ & $\mathrm{MgO}$ & $\mathrm{K}_{2} \mathrm{O}$ & $\mathrm{Na}_{2} \mathrm{O}$ & $\mathrm{SO}_{3}$ & Other \\
\hline 34.8 & 14.23 & 3.59 & 2.78 & 43.12 & 0.6 & 0.4 & 0.11 & 0.09 & 0.37 \\
\hline
\end{tabular}

Sodium carbonate of $\mathrm{CH}$ classification was introduced into the raw mix in the amount of $0.5 ; 1 ; 2 ; 3.5 ; 5 ; 7 \%$ of $\mathrm{Na}_{2} \mathrm{O}$ in equivalent of ignited basis. Tablets weighing $2 \mathrm{~g}$ were formed from obtained mix under manual pressure. In order to avoid $\mathrm{Na}_{2} \mathrm{O}$ volatilization during roasting, the samples were covered with a platinum cup. Roasting of samples was carried out in a laboratory furnace with isothermal time of $20 \mathrm{~min}$. The heating rate of the furnace made $10{ }^{\circ} \mathrm{C} / \mathrm{min}$.

The influence of alkali salts on the formation of aluminate-ferrite phase was estimated according to the content of free calcium oxide and the brightness coefficient of samples. The $\mathrm{CaO}_{\text {free }}$ content in a clinker was defined through ethyl-glycerate method (Butt and Timashev 1973). The whiteness (brightness coefficient) of a clinker was defined via FB-2 reflection meter on a reference polished barium sulfate plate.

\section{Results and Discussion}

The compositions burned at 1250 and $1300{ }^{\circ} \mathrm{C}$ were analyzed. The roasting temperature was chosen based on the following: at given temperatures the formation of belite was complete, and the synthesis of alite had not started yet. As a result, the formation of silicate phases would not change the content of free calcium oxide.

At a temperature of $1250{ }^{\circ} \mathrm{C}$ (Fig. 1) at the initial stage (up to $1 \% \mathrm{Na}_{2} \mathrm{O}$ ) the content of free calcium oxide is reduced alongside with the brightness coefficient (BC). The brightness coefficient almost does not change with $\mathrm{Na}_{2} \mathrm{O}$ concentration in the range of $1-3.5 \%$ and the content of free calcium oxide. With the introduction of over $3.5 \%$ of $\mathrm{Na}_{2} \mathrm{O}$ the $\mathrm{CaO}_{\text {free }}$ content and the brightness coefficient sharply increase.
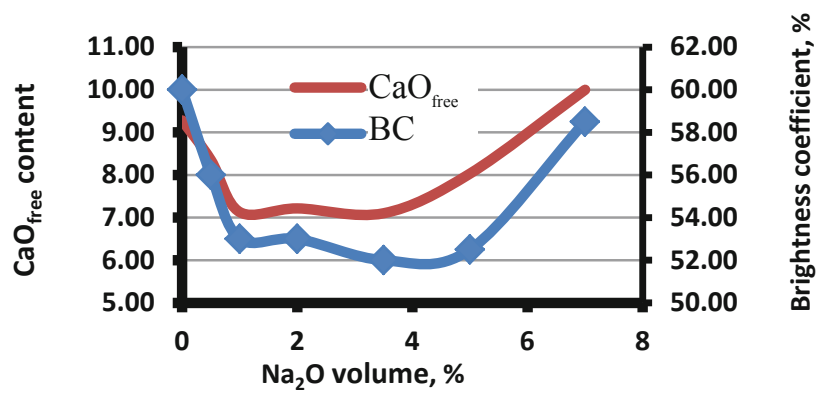

Fig. 1. Influences of $\mathrm{Na}_{2} \mathrm{O}$ on brightness coefficient and content of free calcium oxide at $1250{ }^{\circ} \mathrm{C}$ roasting temperature. 
At a roasting temperature of $1300{ }^{\circ} \mathrm{C}$ (Fig. 2) a similar situation is observed. With the amount of introduced $\mathrm{Na}_{2} \mathrm{O}$ up to $1-2 \%$ the considered characteristics are reduced. Sharp increase of reflection factor and $\mathrm{CaO}_{\text {free }}$ content was also observed in the range of $3.5-7 \%$ of $\mathrm{Na}_{2} \mathrm{O}$.

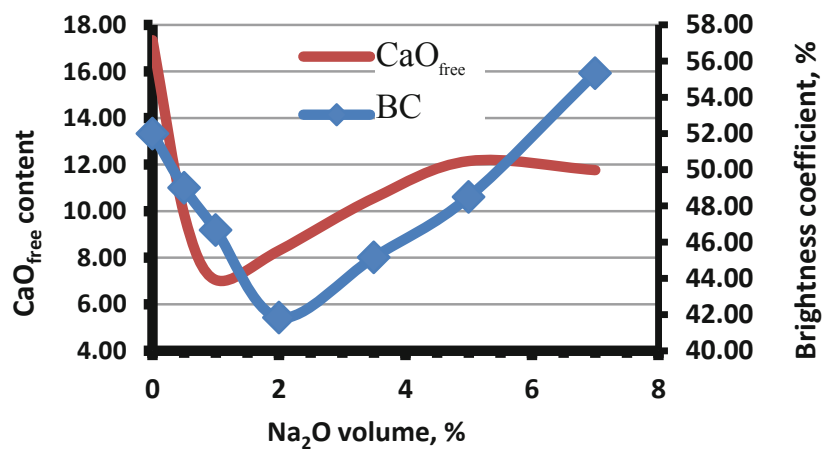

Fig. 2. Influence of $\mathrm{Na}_{2} \mathrm{O}$ on reflection factor and content of free calcium oxide at $1300{ }^{\circ} \mathrm{C}$ roasting temperature.

The relatively low content of free calcium oxide without alite formation may be caused by the formation of intermediate phases, for example carbonate spurrite. The presence of $\mathrm{Na}_{2} \mathrm{CO}_{3}$ in the system fosters its formation. Hence, the increase of $\mathrm{Na}_{2} \mathrm{O}$ content at the initial stage leads to $\mathrm{CaO}_{\text {free }}$ decrease.

The sharp increase of free calcium oxide content starting from $\mathrm{Na}_{2} \mathrm{O}$ concentration of approximately $3.5 \%$ confirms the formation of ferrites or sodium aluminates instead of calcium aluminate ferrites in clinker systems, since such interaction results in the emission of additional amounts of calcium oxide and may be presented by the following reactions:

$$
\begin{gathered}
3 \mathrm{CaO} \cdot \mathrm{Al}_{2} \mathrm{O}_{3}+\mathrm{Na}_{2} \mathrm{O}=2 \mathrm{NaAlO}_{2}+3 \mathrm{CaO} \\
4 \mathrm{CaO} \cdot \mathrm{Al}_{2} \mathrm{O}_{3} \cdot \mathrm{Fe}_{2} \mathrm{O}_{3}+2 \mathrm{Na}_{2} \mathrm{O}=2 \mathrm{NaFeO}_{2}+2 \mathrm{NaAlO}_{2}+4 \mathrm{CaO}
\end{gathered}
$$

The change dependence of brightness coefficient within samples on $\mathrm{Na}_{2} \mathrm{O}$ content in a clinker correlates with the change dependence of free calcium oxide content. This may be explained by the fact that $\mathrm{CaO}_{\text {free }}$ crystals are white. Therefore, the increase or reduction of its content leads to the corresponding change of the brightness coefficient of a clinker. Based on above conclusions, the sharp increase of the brightness coefficient with the increase in $\mathrm{Na}_{2} \mathrm{O}$ concentration of over $3.5 \%$ may also be caused by the complexity of aluminate-ferrite phase. This phase is the most colored part of a clinker (Zubekhin et al. 2004). Hence, the change of its composition and quantity resulting from the formation of aluminates and sodium ferrites will be characterized by the corresponding change of the brightness coefficient of a clinker. 


\section{Conclusions}

The introduction of up to $2-3.5 \%$ of $\mathrm{Na}_{2} \mathrm{O}$ leads to the decrease in the brightness coefficient of samples due to the reduction of free calcium oxide content. Apparently, this is caused by the formation of intermediate phases - carbonate spurrite.

The $\mathrm{Na}_{2} \mathrm{O}$ content of over $3.5 \%$ increases the brightness coefficient of samples. This is caused by the formation of aluminates and sodium ferrites instead of aluminates and calcium aluminate ferrites.

Acknowledgements. The study is implemented in the framework of the Flagship University Development Program at Belgorod State Technological University named after V.G. Shukhov, using the equipment of High Technology Center at BSTU named after V.G. Shukhov.

\section{References}

Butt YM, Timashev VV (1973) Practical Guide on Chemical Technology of Binding Materials: Study Manual. Higher School, p 504

Zubekhin AP, Golovanova SP, Kirsanov PV (2004) White portland cement. Publishing House of Izvestiya Vuzov Journal, Rostov-On-Don, North Caucasian Region, p 264 (Zubekhin AP (ed))

Kovalyov SV (2015) Essentially new method of clinker bleaching with high iron content. In: Kovalyov SV, Mishin DA (eds) International seminar-competition of young scientists and graduate students working in the field of binding materials, concrete and dry mixes: collection of articles: 180 pages. Alitinform Publishing House, Saint Petersburg, pp 29-37

Lisiyenko VG (ed) (2004) Rotary furnaces: thermal engineering, management and ecology. Teplotekhnik, p 688 (Reference edition. Lisiyenko VG, Shchelokov YM, Ladygichev MG) Luginina IG (2002) Selected articles. Publishing House of BSTU named after V.G. Shukhov, Belgorod, p 302

Open Access This chapter is licensed under the terms of the Creative Commons Attribution 4.0 International License (http://creativecommons.org/licenses/by/4.0/), which permits use, sharing, adaptation, distribution and reproduction in any medium or format, as long as you give appropriate credit to the original author(s) and the source, provide a link to the Creative Commons license and indicate if changes were made.

The images or other third party material in this chapter are included in the chapter's Creative Commons license, unless indicated otherwise in a credit line to the material. If material is not included in the chapter's Creative Commons license and your intended use is not permitted by statutory regulation or exceeds the permitted use, you will need to obtain permission directly from the copyright holder.

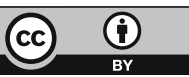

